TEME, г. XLIV, бр. 4, октобар - децембар 2020, стр. 1201-1227

\begin{tabular}{lr}
\hline \hline Оригинални научни рад & https://doi.org/10.22190/TEME190413073M \\
Примљено: 13.4.2019. & UDK 174 \\
Ревидирана верзија: 11. 3. 2020. & 43.352:334.724(497.11) \\
Одобрено за штампу: 1. 12. 2020. &
\end{tabular}

\title{
ЗНАЧАЈ ЕТИЧКЕ КЛИМЕ И КОРУПТИВНИХ РАЦИОНАЛИЗАЦИЈА ЗА НАЧИН РЕШАВАЊА ЕТИЧКИХ ДИЛЕМА НА РАДУ
}

\author{
Небојша Мајсторовић ${ }^{1^{*}}$, Тамара Јовановић ${ }^{2}$, Бојана Ђајић ${ }^{1}$ \\ ${ }^{1}$ Универзитет у Новом Саду, Филозофски факултет, Нови Сад, \\ Република Србија \\ ${ }^{2}$ Универзитет у Новом Саду, Природно-математички факултет, Нови Сад, \\ Република Србија \\ *nebojsamajstorovic6@gmail.com
}

\begin{abstract}
Апстракт
Истраживање је имало за циљ да се утврди значај етичке климе у организацији и прихватања коруптивних рационализација, као индикације нивоа коруптивности, за начин решавања четири етичке дилеме типичне за радни контекст - „истина наспрам лојалности”, „лично наспрам заједничког”, „краткорочно наспрам дугорочног” и „правда наспрам самилости” (Kidder, 1995). На пригодном узорку од 313 запослених из различитих организација у Републици Србији примењен је онлајн-упитник за прикупљање података о перцепцији етичке климе у организацији, склоности ка коруптивним рационализацијама као фактора избора алтернатива у решавању етичких дилема на раду. Налази истраживања указују на значај перцепције егоистичне етичке климе и климе друштвене одговорности за склоност запослених ка самилости у решавању дилеме „правда наспрам самилости”. Закључено је да егоистична етичка клима вероватно генерише прихватање коруптивних рационализација које предвиђају склоност ка „самилости” према крађи имовине компаније. На другој страни, клима социјалне одговорности утиче на опредељење запослених за самилост према онима који крше правила, највероватније јер запослени развијају уверење да је благостање важно, како за клијенте компаније тако и за колеге, чак и када исти прекрше организацијска правила. Закључено је да перцепција организацијске етичке климе индиректно утиче на начин решавања етичких дилема на раду, и то тако што код запослених генерише лична уверења која, потом, утичу на опредељење у решавању етичке дилеме са којим су та уверења у складу.
\end{abstract}

Кључне речи: радна етика, етичке дилеме, коруптивне рационализације, етичка клима. 


\title{
ETHICAL DILEMMAS AT WORK: THE SIGNIFICANCE OF THE ETHICAL CLIMATE AND CORRUPTIVE RATIONALIZATIONS FOR THE RESOLUTION OF ETHICAL DILEMMAS AT WORK
}

\begin{abstract}
The aim of the research was to determine the importance of organizational ethical climate and the levels of corruption for determining the methods of solving the four ethical dilemmas typical of the working environment - "truth versus loyalty", "individual vs. community", "short-term versus long-term" and "justice vs. mercy" (Kidder, 1995). On an ad hoc sample of 313 employees from different organizations in the Republic of Serbia, an online questionnaire was applied for data collecting on the perception of the organizational ethical climate, the tendency towards corruptive rationalizations as factors in choosing alternatives in solving ethical dilemmas at work. The findings indicate the importance of the perception of the egoistic ethical climate and the climate of social responsibility for the willingness of employees to be merciful when solving the dilemma "justice vs. mercy." It was found that the egoistic ethical climate probably generates the acceptance of corruptive rationalizations that predict the acceptance of "mercy" towards those who steal the company's assets. On the other hand, the climate of social responsibility influences the preference of employees for mercy for those who break the rules, most likely because employees develop the belief that well-being is important for both the company's clients and colleagues, even when they violate organizational rules. It was concluded that the perception of the organizational ethical climate indirectly influences the manner of solving ethical dilemmas at work. This is probably done by generating personal beliefs in employees, which then influences the preference for solving the ethical dilemma with which these beliefs are in accordance.
\end{abstract}

Key words: $\quad$ work ethics, ethical dilemmas, corruptive rationalization, ethical climate.

\section{УВОД}

Начин решавања етичких дилема у свакодневном животу и раду има своје директне последице по наше лично благостање, као и благостање људи око нас. Наиме, решење етичке дилеме може бити или у складу или у нескладу са личним и/или организацијским моралним вредностима. Истраживања показују да су етичке вредности централне за позитивну слику о себи (Chaiken, Giner-Sorolla, \& Chen, 1996), да људи желе да опажају себе и у прошлости као поштене (Greenwald, 1980), да чак 84\% адолесцената, студената и одраслих особа то и каже за себе (Aquino \& Reed, 2002), да су склони и самообмањивању како би то и остали (Tajfel, 1982) и да развијају посебне стратегије у оцењивању своје моралности како би такву слику и очували (Barkan et al., 2012). Свакако да решења етичких дилема која значе очување слике о себи доводе особу до доживљаја личног интегритета и среће. Аристотел описује 14 етичких врлина попут умерености, племенитости, поноса или правичности и истиче да особа може достићи личну срећу (еудаимонија) само ако се руководи врлинама у свакодневном животу, односно, ако тежи ка средини између 
претераности и недостатка. Савремена истраживања указују на повезаност поштења, праведности према другима, поштовања и бриге о другима, са једне стране, и еудаимоничне среће и субјективног благостања, са друге стране (нпр., James, 2011; Garcia и др., 2007). Примећено је и да перцепција корупције, низак грађански активизам и ниско поверење у људе умањују осећај личне среће и благостања (Tavits, 2009; Bjørnskov, 2003). Индустрије које данас развијамо обезбеђују човеку прегршт производа и услуга, али стварање таквог обиља мора ићи скупа са друштвеном одговорношћу према данашњици, као и према будућности заједнице у којој се послује (нпр., Cecchi, 2007). Део таквог социјално одговорног пословања било које организације представља и уређивање радне етике како би њени запослени имали јасан оквир за решавање етичких дилема са којима се сусрећу у раду. Овакав оквир обезбеђује очување личног интегритета запосленог, али и избегавање кршења локалних, односно организацијских, етичких норми.

\section{ТЕОРИЈСКИ ОКВИР}

\section{Етичке дилеме у раду: одређење и класификаиија}

Етичка дилема се описује као одлучивање уз присуство сукоба два етичка принципа или више њих. Ферел (Ferrell, 2010, стр. 64) и сарадници наводе да је етичка дилема „...проблем, ситуација или шанса која тражи од појединца, групе или организације да изабере између неколико погрешних или неетичних радњи". Наиме, етичка дилема је било која ситуација одлучивања у којој постоји контрадикција између наочиглед једнаковредних етичких принципа, а избором једног од њих увек настају и негативне консеквенце по неку од страна које су укључене у такву ситуацију. Избор није између „исправног наспрам погрешног”, односно, у прихватању или одбијању да се због неког личног добра некоме другоме нанесе зло, него се особа налази пред избором између „исправног наспрам исправног”, односно, пред избором доброг решења којим ће произвести најмање зла било коме. На пример, запослени може бити свестан да његова радна група својим понашањем крши етичке норме важеће у организацији и да тиме остварује додатну корист за своје чланове. Он/она ће бити у дилеми да ли да пријави такво понашање и поштује принцип истинољубивости или да се приклони групи, покаже лојалност према њој и не говори о уоченим преступима у пословању. Ако се определи за лојалност групи, особа ће претрпети штету, односно, његово/њено лично благостање ће бити умањено због жртвовања сопственог интегритета, нарушавања његовог односа према организацији и одрицања од истинољубивости. Међутим, ако се определи за истинољубивост, особа ће највероватније жртвовати своје односе са члановима 
те групе, изгубиће користи које има са том групом, као што ће вероватно проузроковати и то да и други изгубе користи које имају од понашања такве групе (ово препознајемо као појаву узбуњивача).

Важно за истраживање етичких дилема на раду је свакако и њихова потенцијална класификација. У овом раду користићемо класификацију коју је понудио Рашворт Кидер (Kidder, 1995), а према којој менаџери и извршиоци у свом раду најчешће решавају ове четири етичке дилеме: 1) истина наспрам лојалности, 2) лично наспрам заједничког, 3) краткорочно наспрам дугорочног и 4) правда наспрам самилости. Ове дилеме почивају на конфликту вредности које потичу из различитих етичких теорија, а њихово решавање подразумева опредељивање за један од полова који је чине. На пример, етичка дилема „истина наспрам лојалности” означава ситуацију у којој запослени тражи решење док се сучељавају поштење или интегритет, на једној страни, и преданост групи, одговорност за преузете обавезе или за дато обећање, на другој страни. Мерена су два аспекта сваког пола ове дилеме: пријављивање колеге или свих незаконитих радњи у организацији, као аспекти истине, а беспоговорно слушање претпостављеног и толеранција према наношењу штете окружењу, као аспекти лојалности.

\section{Решавање етичких дилема на раду}

Решавање етичких питања на раду је сложен и захтеван когнитивни задатак, који, поред тога, носи одговорност према свим странама укљученим у производни процес, као и према спољашњој средини организације. О сложености процеса индивидуалног етичког одлучивања говори и чињеница да је до сада понуђен велики број модела који се могу поделити на контраинтуитивне (рационалне) и интуитивне моделе (засноване на моралним осећањима). ${ }^{1}$ Такође, Вајлд и Џоунс (Wylde \& Jones, 1997), Зоненшајн (Sonenshein, 2007), Мекдевит, Ђиапони и Тромли (McDevitt, Giapponi and Tromley. 2007), а потом и Тревињо, Ден Ниевенбор и Киш-Гефарт (Treviño, Den Nieuwenboer and Kish-Gephart, 2014) наводе још неке новије моделе индивидуалног етичког одлучивања. Поред модела који описују са̂м процес како особа доноси етичку одлуку, Ферел, Фридрич и Ферел (Ferrell, Freadrich \& Ferrell, 2010) развијају и модел који наводи факторе од којих зависи успешност етичког суђења у организацији (Слика 1$)$.

\footnotetext{
${ }^{1}$ На пример, Џонс (Jones, 1991) описује седам модела етичког одлучивања насталих током 80-их година прошлог века: Рест (Rest, 1986), Тревињо (Trevino, 1986), Ферел и Грешам (Ferrell and Gresham, 1985), Хант и Вител (Hunt and Vitell, 1986), Дубински и Локен (Dubinsky and Loken, 1989), Ферел, Грешам и Фридрич (Ferrell, Gresham and Freadrich, 1989), Бромер, Грато, Гравендер и Татл (Brommer, Gratto, Gravenderand Tuttle, 1987).
} 


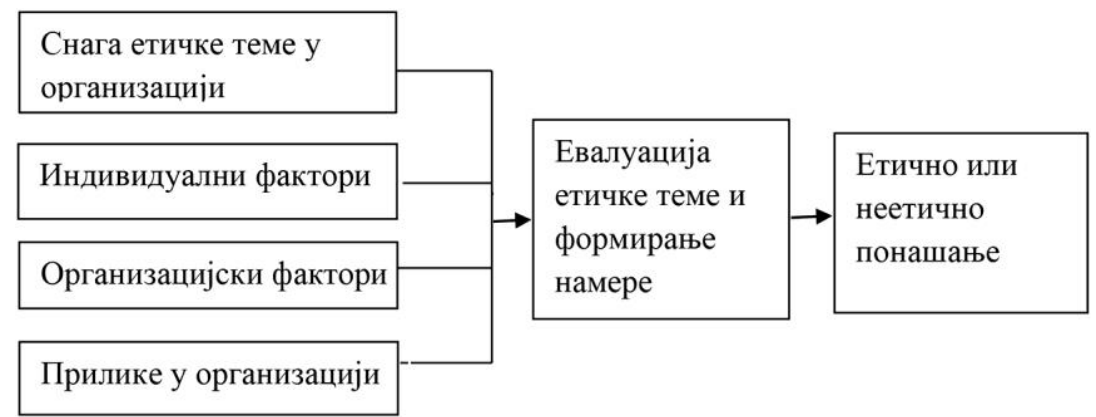

Слика 1. Групе фактора значајних за доношење етичких одлука на раду (Ferrell и др., 2010)

У нашој земљи и нашем окружењу истраживања етичких дилема су ретка и спроведена су не са циљем анализе фактора у њиховом решавању, него да би такве дилеме биле описане као, на пример, у професији полицајца (Кесић и Зекавица, 2013) или у медијима (Донев и Калуђеровић, 2016), у социјалном раду (Urbanc, 2001) или етичке дилеме у истраживањима са осетљивим друштвеним групама (Andrijanić, 2018).

У овом истраживању пажња ће бити посвећена значају организационог фактора (етичка клима), као и индивидуалног фактора (овде коруптивних рационализација) за процес евалуације и начина решавања етичких дилема на раду. Отуда ће у наставку ови фактори бити концептуално одређени заједно са приказом налаза из релевантних истраживања.

\section{Етичка клима у организащији}

Аутори изворног теоријског модела организацијске етичке климе (перцепција регулатива, политика, праксе и реалних образаца понашања у организацији) укрштају две димензије - етички критеријум за оцену прихватљивости понашања (егоизам, беневолентност и принципијелност) и ниво етичке анализе понашања (индивидуални, локални и космополитски), на основу чега дефинишу девет теоријских типова етичке климе (Victor \& Cullen, 1988).

Егоизам на индивидуалном, локалном и космополитском нивоу производи три типа етичке климе: лични интерес (заступа интерес појединца), профит компаније (одлучивање које штити интересе компаније и ставља их изнад личних интереса) и ефикасност (етичко одлучивање које води рачуна о интересима ширег окружења). Алтруизам на индивидуалном, локалном и космополитском нивоу производи три типа етичке климе: колегијалност (пријатељство, одлучивање које промовише осетљивости на потребе блиских особа без обзира на њихову радну улогу у организацији), тимски интереси (за- 
ступање интереса колектива као целине) и друштвена одговорност (одлучивање које промовише друштвено одговорно пословање организације). И, на крају, димензија принципијелност на индивидуалном, локалном и космополитском нивоу даје три типа етичке климе: лична моралност (подршка развоју личних етичких принципа у решавању етичких дилема), организацијска правила и процедуре (истицање етичких принципа организације) и Закон и професионалне норме (промоција етичких стандарда садржаних у законима и кодексима професија). Каснијом валидацијом модела аутори су показали постојање седам типова етичке климе (Cullen, Victor \& Bronson, 1993).

Емпиријска истраживања показују да организацијска етичка клима заиста има значаја за етичко одлучивање, као и намере за етично понашање запослених. Гош (Ghosh, 2008) налази да, уколико се у организацији вреднује и награђује искључиво финансијски резултати рада, упосленици доносе значајно више неетичних одлука у поређењу са организацијама у којима се награђују интегритет и добра пословна пракса. Етичка клима организације има позитивног ефекта на формирање намере за етично понашање, односно, перцепција развијених стандарда за решавање етичких дилема у организацији помаже запосленима да формирају етичне намере (Valentine \& Barnett, 2007; Elango и др., 2010). Даи (Dai, 2012) на основу прегледа резултата 15 студија, које су се у периоду од 2004. до 2010. године бавиле анализом значаја организацијских фактора, закључује да је у 6 студија утврђен позитиван ефекат етичке климе на етично понашање запослених, 7 студија није утврдило значајан ефекат, а да су 2 студије известиле о помешаним ефектима.

У домаћим истраживања нема анализа релација етичке климе и решавања етичких дилема на раду. Истраживања вршена са неким другим циљем показују да етичке климе „пријатељство и тим” и клима „закон и кодекс" доприносе бољем психо-физичком здрављу упосленика, док перцепција егоистичне етичке климе изазива депресивне реакције и симптоме поремећаја друштвеног понашања (Коларски, 2019).

\section{Коруптивне рацчионализације}

Уколико током етичког одлучивања настане несклад између одлуке и личних етичких стандарда, понашање ће код актера произвести стање етичке дисонанце или „моралног стреса” (Waters \& Bird, 1987; Мајсторовић, 2012; Barkan и др., 2015). На пример, руководилац може запасти у стање етичке дисонанце ако под притиском свог шефа прихвати да његови извршиоци у аутомобил уграде део који због лошег квалитета може да угрози безбедност возача. Стање етичке дисонанце је еквивалент стању когнитивне дисонанце (Festinger, 1962), са том разликом да ово стање прати и осећај кривице с обзиром на то да неетично понашање увек крши и неке социјалне норме. 
Особи су на располагању два начина да отклони овакво непријатно стање: 1) да оправда своју одлуку коришћењем рационализација (нпр., и други то раде) и тиме наруши сопствене етичке стандарде или 2) да промени понашање (да следећи пут одбије такво искушење преузимајући ризик од последица одбијања) и тиме сачува етичке принципе. Коришћење коруптивних рационализација омогућава особи да, и поред тога што је донела одлуке штетне по организацију, и даље себе види као некорумпирану (Zuglidopoulos и др., 2009). Отуда, можемо да кажемо да је склоност појединца ка прихватању коруптивних рационализација врло вероватна индикација његове коруптивности. По себи, коруптивне рационализације представљају „когнитивне конструкције које особа креира како би оправдала сопствено неприхватљиво понашање, настојећи тиме да се такво понашање или прихвати, или да се барем не реагује против њега" (Мајсторовић, 2012, стр. 60). Оне се јављају као лични механизам релаксирања савести или као механизам коруптора којим он/она релаксира друге током њихове социјализације на норме неусклађене са организацијским и/или другим здравим етичким стандардима. На тај начин, ширење коруптивних рационализација доводи и до ескалације корупције у организацији. Ашфорт, Ананд и Јоши (Aschfort, Anannd $\&$ Joshi, 2004) описују 9 типова коруптивних рационализација, од којих ће њих 6, због подесности за упитнички формат, бити испитано у овом истраживању.

1. Легалност коруптивног чина своди се на одрицање незаконитости чина, обично критиковањем квалитета закона или његовом селективном применом у пракси;

2. Порицање одговорности значи избегавање и пребацивање одговорности на друге или на уобичајену праксу која је својствена свима;

3. Порицање штете манифестује се у минимизирању последица чина у смислу да изазвана штета за компанију заиста није ништа значајно;

4. Порицање постојања жртве јавља се када је штета нанета организацији праведан одговор на претходни неправедан поступак према актеру или одрицање важности штете према претходно деперсонализованој особи у групи;

5. Социјално вредновање јавља се онда када актер пореди свој чин са другима чије поступке оцењује далеко неморалнијим од својих;

6. Лојалност групи своди се на оправдавање жртвовања индивидуалних или универзалних вредности како би се „заштитила” група којој актер припада (Мајсторовић, 2012, стр. 60-61).

Код нас је утврђено да су запослени превалентно склони ка два типа рационализација: „социјалном одмеравању” и ,лојалности групи” (Матановић, Мајсторовићи Митрић-Аћимовић, 2011; Мартиновић, 2012). У случају интегрисане регулације (интегрисани селф - регула- 
ција заснована на аутентичним вредностима интегрисаним у селф особе), таква склоност у потпуности изостаје (Мајсторовић, 2012). Слично, Мартиновић (2012) примећује да су ниска интегрисана регулација, али и макијавелистичка радна етика, показатељи склоности ка свим мереним коруптивним рационализацијама.

\section{Демографске одлике и етичност}

Испитивања значаја демографских одлика на етичко одлучивање показују виши ниво моралности код жена на узорку студената и менаџера (Becker, Rundall \& Ulstad, 2009; Valentine \& Rittenburg, 2007; Lawson, 2004), чешће утилитаристичко морално суђење код мушкараца (Zgheib, 2005), да старост и ниво образовања не утичу на морално суђење (Herington \& Weaven, 2008; Marques \& AzevedoPereira, 2009). Када је реч о значају демографских одлика за учесталост коруптивних рационализација, истраживања у Србији показују да нема полних разлика у њиховом прихватању (Мајсторовић, 2012), да запослени у приватним компанијама показују нижу склоност ка рационализацијама него запослени у државном сектору, да су старији склонији „лојалности групи” него млађи, као и да су рационализацијама склонији запослени са завршеном средњом школом у односу на високообразоване (Мартиновић, 2012).

\section{ПРОБЛЕМ И ЦИЉЕВИ ИСТРАЖИВАЬА}

Аутори се у овом истраживању баве питањем да ли перцепција одређених типова етичке климе у организацији и склоност коруптивним рационализацијама остварују ефекат на специфична опредељења запослених према половима етичких дилема типичних за организацију - „истина наспрам лојалности”, „правда наспрам самилости”, „индивидуално наспрам заједничког” и „краткорочно наспрам дугорочног”. Отуда, главни циљ овог истраживања је утврдити да ли перцепција одређених етичких стандарда, образаца понашања и праксе у организацији и прихватање одређених коруптивних рационализација остварују значајан ефекат на преференцију појединих полова у решавању типичних организацијских етичких дилема. Сем тога, циљ рада је и да се, на основу резултата истраживања, предложе конкретне мере менаџменту које би требало да унапреде радну етику организације. Коначно, биће анализиран значај пола, старости и нивоа образовања за начин решавања етичких дилема, као и значај типа етичке климе у организацији за склоност коруптивним рационализацијама код њених запослених.

Претходна истраживања су врло бројна у домену моделирања процеса етичког одлучивања у организацији, што се види по броју прегледних чланака оваквих модела из 80-их година прошлог века 
(Jones, 1991) или из каснијег периода (Loe et al., 2000) који разматрају бројне теоријске моделе и факторе који утичу на процес одлучивања. Међутим, недостају истраживања у домену фактора решавања врло конкретних етичких дилема са којима се менаџери најчешће сусрећу у раду. Отуда, претпоставке овог рада биће засноване на истраживањима фактора етичког одлучивања, намера и понашања иако се они директно не односе на избор алтернатива у наведеним етичким дилемама. Када је реч о значају коруптивних рационализација у односу на начин решавања етичких дилема и у односу на етичку климу, претпоставке ће бити засноване искључиво на њиховим концептуално могућим односима, јер претходних истраживања ове врсте такође нема.

X1: Постоји повезаност перцепције типова етичке климе у организацији који промовишу егоизам и личне интересе, са једне стране, и преференција код чланова те организације које значе залагање за лично и краткотрајно благостање у решавању етичких дилема, са друге стране.

$\mathrm{X} 2$ : Демографске одлике делом утичу на начин решавања етичких дилема на раду:

X2.1: Очекује се да жене показују мању склоност ка утилитарном етичком суђењу, односно слабију оријентацију ка личном и краткорочном;

$\mathrm{X} 2.2$ : Очекује се да ниво образовања не утиче на начин решавања етичких дилема на раду;

X2.3: Очекује се да старост не утиче на начин решавања етичких дилема на раду.

Х3: Постоји повезаност склоности ка коруптивним рационализацијама и преференције личног, краткотрајног интереса и лојалности групи - као полова етичких дилема на раду.

X4: Постоји повезаност перцепције одређених типова организацијске етичке климе и склоности чланова те организације према одређеним врстама коруптивних рационализација.

\section{МЕТОД}

Узорак испитаника

Подаци су прикупљени на пригодном узорку од 317 запослених из различитих компанија у Републици Србији. Већину у узорку чиниле су жене $(89,8 \%)$, са радним стажом од 1 године до 37 година и углавном са факултетском дипломом $(62,5 \%)$. Испитаници су категорисани према годинама старости на групе „до 30 година” $(29,4 \%)$, „од 31 године до 40 година” (33.5\%), „од 41 године до 50 година” $(22.7 \%)$ и „од 51 године и више година” $(14,4 \%)$. Након одстрањива- 
ња 4 испитаника са стандардизованим скоровима већим од 3,29 (Tabachnick \& Fidell, 2007), коначан узорак чинило је 313 испитаника.

\section{Мерни инструменти}

Скала Е-ДИЛ-3 (Мајсторовић, Пилиповић, Ђајић и Ристић, 2018) конструисана је за потребе овог истраживања и процењује склоност запослених да се током решавања етичких дилема определи за један од њених полова. Инструмент чини 16 ставки, по две за сваки пол унутар четири етичке дилеме. Од испитаника се тражи да се поред сваке ставке изјасни са „да”, ако је сагласан са решењем етичке дилеме, или „не”, ако са понуђеним решењем није сагласан. На пример, ставка „Чак и по цену сопствене штете пријавио/-ла бих незаконите радње у компанији” мери склоност ка полу „истина” у оквиру дилеме „истина наспрам лојалности”. Или, ставка која мери склоност ка полу „лојалност” „Увек бих стао/-ла у одбрану своје компаније ако би је неко позвао на одговорност због загађења животне средине, без обзира на то какве доказе имао". Меру склоности представља збир прихваћених решења за сваки пол етичке дилеме са теоријским распоном скорова од 0 до 2. С обзиром на то да овде није реч о упитнику који мери један конструкт, него о колекцији ставки које мере степен склоности ка 8 решења (полова дилема), која потичу из различитих етичких парадигми, логично је очекивати да одговори испитаника не могу бити конзистентни дуж целог упитника. Отуда, не може се очекивати ни интерна конзистентност реакција испитаника дуж целог упитника. Корелације између парова ставки по супскалама крећу се од 0,31 до 0,72 , а просечна корелација износи 0,48 . Наведено је у складу са искуством да је коефицијент интерне конзистенције увек врло низак код скала са малим бројем ставки и са препоруком да код скала са два ајтема прихватљива корелација између њих буде од 0,20 до 0,40 (Briggs \& Cheek, 1986). Важно је још једном истаћи да није рачунат укупан скор на упитнику, него да су анализе рађене искључиво на супскалним скоровима као мерама склоности појединачном полу сваке етичке дилеме.

Познати Упитник етичке климе ECQ (Victor \& Cullen, 1988, $1993)$ преведен је и прилагођен за потребе истраживања на нашој популацији (Мајсторовић и Слијепчевић, 2018; Драгин и др., 2018) и коришћен је за мерење перцепције етичке климе у овом истраживању. Унапређену скалу са 36 ставке (у почетку 4 ставке за сваки тип етичке климе) аутори су валидирали и утврдили постојање 7 типова етичке климе: „егоизам”, „профит и ефикасност”, „пријатељство и тим”, „,социјална одговорност”, „,ична моралност”, „правила и процедуре” и клима „закона и професионалних кодекса“. С обзиром на то да се на тај начин број ставки разликује по типовима етичке климе, индивидуални скор за сваки тип климе рачунат је као средња 
вредност одговора испитаника на односним ставкама. На пример, ставка „У мојој организацији људи се углавном брину само о себи” мери егоистични тип етичке климе за коју испитаник процењује у којој мери је она присутна у његовој/њеној организацији користећи скалу од „1- уопште не” до „,5 - у потпуности да”. Према ауторима скале, провере интерне конзистентности показују да мере типова етичке климе имају интерну конзистентност $(\alpha)$ од 0,69 до 0,85 (Cullen, Victor \& Bronson, 1993).

Упитник КоПТеР-2 (Мајсторовић, 2011) коришћен је за мерење склоности испитаника према шест врста коруптивних рационализација: одрицање нелегалности, порицање одговорности, порицање штете, порицање жртве, социјално вредновање и лојалност групи. Упитник садржи 18 ставки (3 ставке за сваку врсту рационализациja), на које испитаник одговара заокруживањем степена слагања на петостепеној скали одговора (од 1 - потпуно нетачно до 5 - потпуно тачно). На пример, ставка „Све што не пише у закону да је забрањено значи и да је дозвољено" мери склоност ка одрицању нелегалности коруптивног поступка. Скор на тесту је збир одговора на ставкама које карактеришу сваку врсту коруптивних рационализација појединачно, а теоријски распон је од 3 до 15. Анализа метријских својстава показује да овај упитник има задовољавајућу интерну конзистентност $(\alpha=0,79$; Мартиновић, 2012).

\section{Начин прикупљања података}

Прикупљање података спроведено је током лета 2018. године помоћу анонимне и добровољне онлајн-анкете постављене на различите друштвене мреже. Испитаници су на почетку добили кратко објашњење о циљу истраживања, начину попуњавања упитника и исказ о поверљивом коришћењу прикупљених података. Попуњавање упитника трајало је око 30 минута.

\section{Начин обраде података}

Прикупљени подаци су проверени у смислу њиховог квалитета, а потом обрађени уз примену техника дескриптивне и инференцијалне статистике. Конкретно, релације независних и зависних варијабли анализиране су помоћу вишеструке регресијске анализе, док су међугрупне разлике тестиране применом т-теста и једносмерном анализом варијансе. Желимо да напоменемо да су, због предоминације испитаника женског пола у узорку, полне разлике тестиране на рандомизираном подузорку жена који је по броју био једнак подузорку мушкараца. Све анализе су спроведене применом статистичког програма SPSS (верзија 23.0). 


\section{РЕЗУЛТАТИ}

Резултати овог истраживања биће приказани у три дела: 1) опис учесталости опредељења испитаника према половима етичких дилема, опис учесталости перцепције мерених типова етичке климе и опис учесталости склоности ка мереним коруптивним рационализацијама; 2) провера хипотеза истраживања и 3) дискусија налаза.

Опис учесталости мерених конструката

Из Табеле 1 и Слике 2 може се уочити да у решавању етичких дилема на раду наши испитаници радије бирају истину насупрот лојалности, заједничко насупрот личном, самилост насупрот правди и дугорочно насупрот краткорочном.

Табела 1. Дескриптивне мере преференција полова етичких дилема $(H=313)$

\begin{tabular}{lccc}
\hline Полови етичких дилема & АС & СД & Распон мера \\
\hline Истина & 0,85 & 0,68 & $0-2$ \\
Лојалност & 0,36 & 0,57 & $0-2$ \\
Лично & 0,21 & 0,47 & $0-2$ \\
Заједничко & 1,03 & 0,68 & $0-2$ \\
Правда & 0,84 & 0,68 & $0-2$ \\
Самилост & 1,24 & 0,65 & $0-2$ \\
Краткорочно & 0,62 & 0,68 & $0-2$ \\
Дугорочно & 1,59 & 0,63 & $0-2$ \\
\hline
\end{tabular}

*Напомена: АC - аритметичка средина, СД - стандардна девијација

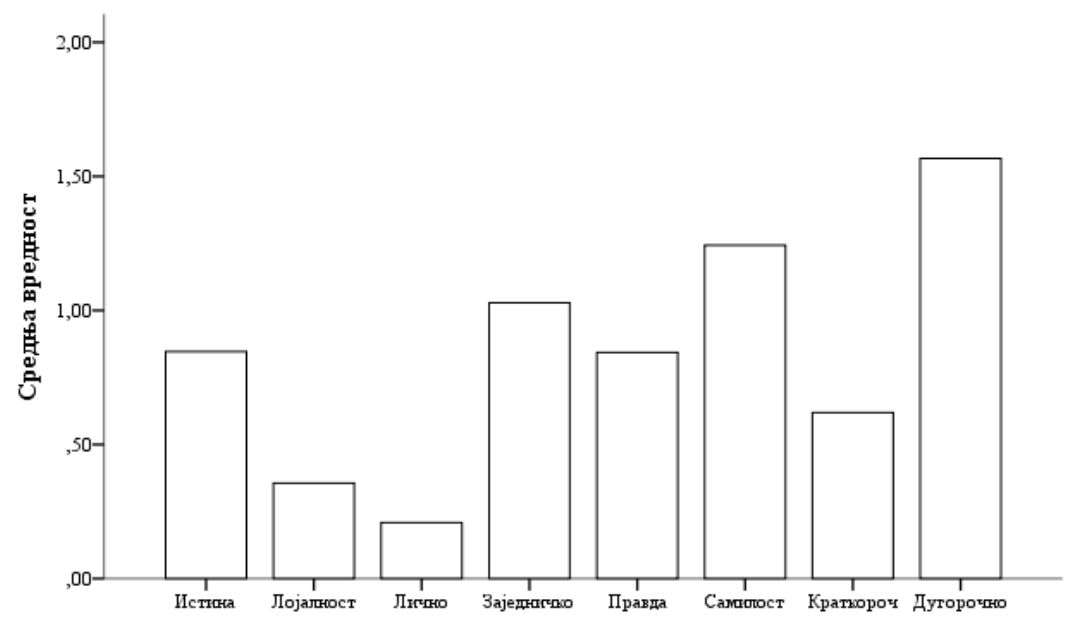

Слика 2. Учесталост прихватања полова етичких дилема 
Разлике између преференција полова код свих етичких дилема је скоро двострука, осим код дилеме правда насупрот самилости, где су преференције ова два пола више уједначене. Наиме, наши испитаници се код три од четири мерене дилеме недвосмислено опредељују за један од полова (нпр., просечна учесталост прихватања пола „истина” је 0,36 а пола „лојалност” 0,85).

Када је реч о перцепцији етичке климе у организацијама, показало се да наши испитаници у својим организацијама најређе препознају климу пријатељства и тимског духа, а најчешће стандарде који се заснивају на законима и на кодексима професионалног понашања (Табела 2 и Слика 3 ).

Табела 2. Дескриптивне мере за периепиију типова етичке климе $(H=313)$

\begin{tabular}{lccc}
\hline Типови етичке климе & АС & СД & Распон мера \\
\hline Егоизам & 3,40 & 0,90 & $1-5$ \\
Профит & 3,74 & 0,88 & $1-5$ \\
Тим & 2,70 & 0,98 & $1-5$ \\
Соц. одгов. & 3,56 & 0,93 & $1-5$ \\
Лична мор. & 3,13 & 0,70 & $1-5$ \\
Правила & 3,82 & 0,86 & $1-5$ \\
Закони/Кодекс & 3,98 & 1,04 & $1-5$ \\
\hline
\end{tabular}

"Напомена: АC - аритметичка средина, СД - стандардна девијација

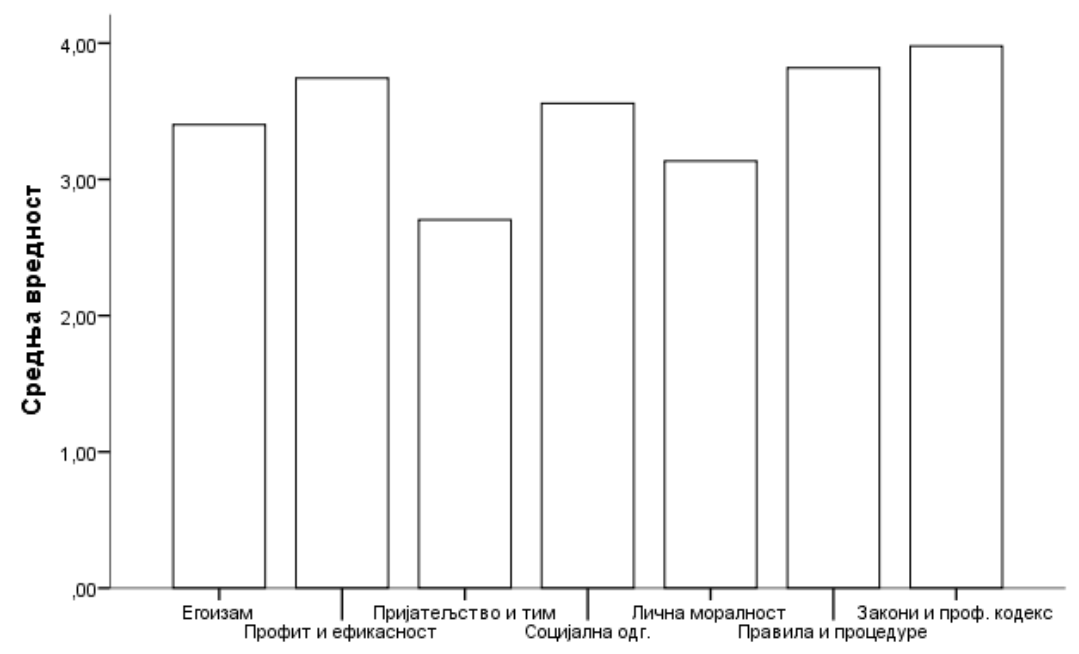

Слика 3. Периепиија присуства седам типова етичке климе у организаиијама

На крају, током решавања стања етичке дисонанце наши испитаници највиши ниво склоности коруптивним рационализацијама 
показују према „лојалности групи” и „,социјалном вредновању”, док су најмање склони „порицању жртве” (Табела 3 и Слика 4).

Табела 3. Дескриптивне мере склоности ка коруптивним рационализацијама $(H=313)$

\begin{tabular}{lccc}
\hline Коруптивне рационализације & АС & СД & Распон мера \\
\hline Порицање нелегалности & 5,65 & 1,83 & $3-11$ \\
Порицање одговорности & 5,15 & 1,65 & $3-11$ \\
Порицање штете & 4,00 & 1,44 & $3-11$ \\
Порицање жртве & 3,97 & 1,30 & $3-10$ \\
Социјално вредновање & 6,03 & 2,16 & $3-12$ \\
Лојалност групи & 6,07 & 1,93 & $3-12$ \\
\hline
\end{tabular}

*Напомена: АС - аритметичка средина, СД - стандардна девијација

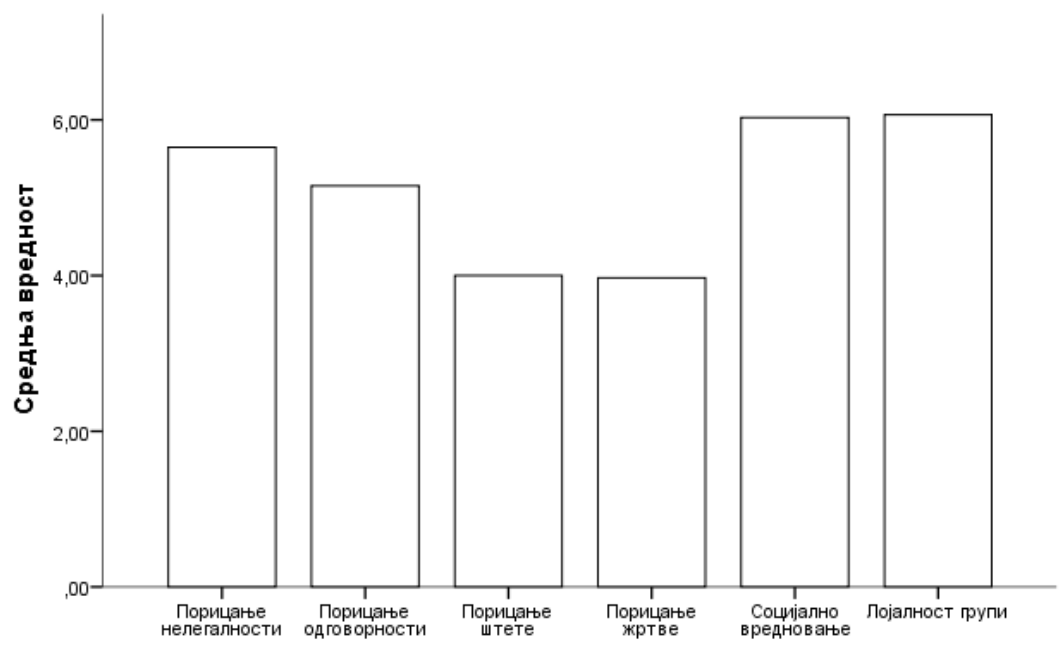

Слика 4. Степен прихватања коруптивних ращчионализащчија

Претходни дијаграми указују на тенденцију код запослених да, када решавају етичке дилеме на раду, најчешће бирају дугорочну перспективу и заједничке интересе, али и самилост према колегама и чешће залагање за истину него за лојалност. У својим организацијама најчешће препознају климу закона и професионалног кодекса, климу правила и процедура, климу ефикасности и профита, док најређе наилазимо на климу пријатељства и тимског духа. На крају, када користе рационализације да оправдају коруптивно понашање, наши запослени то најчешће чине жртвујући принципе зарад добра свога клана, указујући на преступе других да би минимизирали своје и одричу незаконитост у својим коруптивним поступцима. 


\section{Провера хипотеза истраживања}

Резултати показују да је перцепција етичке климе у организацији систематски предиктор једино склоности ка самилости у решавању етичке дилеме „правда наспрам самилости” (X1) (Табела 4). Анализом доприноса типова етичке климе у једином значајном моделу утврђено је да склоност ка самилости (насупрот правди) прогнозирају организацијска клима егоизма, $\beta=0,18, \mathrm{t}(305)=2,62, \mathrm{p}<0,01$ и клима друштвене одговорности: $\beta=0,21, \mathrm{t}(305)=2,83, \mathrm{p}<0,001$.

\section{Табела 4. Регресијски модели са половима етичких дилема као критеријским и типовима етичке климе као предикторским варијаблама}

\begin{tabular}{lccccc}
\hline Критеријум & $\mathrm{R}$ & $\mathrm{R}^{2}$ & $\mathrm{df}$ & $\mathrm{F}$ & $\mathrm{p}$ \\
\hline Истина & 0,153 & 0,024 & 7,305 & 1,050 & 0,396 \\
Лојалност & 0,116 & 0,013 & 7,305 & 0,593 & 0,762 \\
Правда & 0,172 & 0,030 & 7,304 & 1,329 & 0,236 \\
Самилост & 0,229 & 0,052 & 7,305 & $2,405^{*}$ & 0,021 \\
Лично & 0,181 & 0,033 & 7,305 & 1,483 & 0,173 \\
Заједничко & 131 & 0,017 & 7,305 & 0,766 & 0,617 \\
Краткорочно & 177 & 0,031 & 7,305 & 1,411 & 0,200 \\
Дугорочно & 165 & 0,027 & 7,305 & 1,215 & 0,294 \\
\hline \multicolumn{5}{c}{ Тест значајан на нивоу 0,05 (двострано). } \\
& *** Тест значајан на нивоу 0,01 (двострано). &
\end{tabular}

Дубља анализа значаја типова етичке климе као предиктора извршена је спрам два мерена аспекта самилости: самилост према запосленом који због немаштине краде имовину компаније и самилост према запосленом који крши правила понашања у компанији. Резултати ове анализе показују да једна од мера егоистичне климе (ставка „У мојој организацији људи пре свега воде рачуна да заштите своје интересе") прогнозира самилост према крађи: $\beta=0,14, \mathrm{t}(305)=2,54$, $\mathrm{p}<0,01$. На другој страни, једна од мера егоистичне климе (ставка „У мојој организацији људи се брину само о себи”), $\beta=0,15, \mathrm{t}(305)=$ $2,54, \mathrm{p}<0,01$ и једна од мера климе друштвене одговорности (ставка „У мојој организацији запослени се активно баве тиме шта је у интересу клијента-потрошача и шире јавности"), $\beta=0,13, \mathrm{t}(305)=$ $2,32, \mathrm{p}<0,02$ - прогнозирају самилост према запосленима који крше организацијска правила. Утисак је да они који описују етичку климу своје организације као егоистичну, као и они који примећују да су запослени активно укључени у заштиту благостања својих потрошача и свих других укључених у пословање - показују и самилост ако ти исти запослени крађом компензују своје сиромаштво или ако прекрше правила понашања у организацији. Чини се да два типа етичке климе подстичу одређену индивидуалну динамику која доводи до 
формирања наклоности према онима који краду услед економске угрожености или до наклоности према онима који прекрше интерна правила понашања. С обзиром на то да перцепција егоистичне климе не прогнозира склоност ка личном и краткотрајном у решавању етичких дилема на раду, можемо констатовати да прва хипотеза (X1) није потврђена.

Анализа полних разлика према склоности ка одређеним решењима етичких дилема (X2.1) показала је да жене показују значајно више склоности ка истини него мушкарци, док мушкарци показују више склоности ка лојалности (Табела 5).

Табела 5. Полне разлике у решавању етичких дилема на раду.

\begin{tabular}{|c|c|c|c|c|c|}
\hline \multirow{2}{*}{ Варијабле } & \multicolumn{2}{|c|}{ Жене (32) } & \multicolumn{2}{|c|}{ Мушкарци (32) } & \multirow[b]{2}{*}{$t(62)$} \\
\hline & $\mathrm{M}$ & SD & $\mathrm{M}$ & SD & \\
\hline Истина & 0.88 & 0.66 & 0,47 & 0,51 & $2,76^{* *}$ \\
\hline Лојалност & 0,31 & 0,59 & 0,66 & 0,75 & $2,04^{*}$ \\
\hline
\end{tabular}

Резултати анализе варијансе показали су да се старосне групе испитаника значајно разликују у смислу да су запослени до 30 година година старости $(\mathrm{M}=3,15, \mathrm{SD}=0,55)$ значајно склонији ,,личном” у решавању дилеме „лично насупрот заједничком” у односу на запослене са 51 годином и више година старости $(\mathrm{M}=0,61, \mathrm{SD}=$ $0,47),(F(3,309)=3,99, p<0,01)$. Ниво образовања (средње, више и високо) не остварује статистички значајан ефекат на преференцију било којег пола у решавању четири етичке дилеме на раду (вредности F-тестова крећу се од 0,10 до 1,63 за степене слободе 2 и 310).

На основу ових налаза можемо констатовати да X2.1 није потврђена, односно да жене не показују значајно мању склоност ка личном и краткорочном (индикације утилитарне етике). Хипотеза X2.2 потврђена је налазом да ниво образовања не игра улогу у формирању склоности ка одређеним половима етичких дилема. Хипотеза X2.3 није потврђена јер је утврђено да запослени до 30 година старости, када решавају етичку дилему „лично наспрам заједничком” радије бирају „лично” значајно чешће од запослених који имају преко 51 године старости.

Склоност ка свим мереним коруптивним рационализацијама остварује очекиване везе са опредељењем за лични интерес, краткорочну перспективу и лојалност (X3). Наиме, Пирсонове корелације показују да виши ниво укупне коруптивности коварира највише управо са склоношћу ка личном и краткорочној перспективи, али и са склоношћу ка самилости и негативно са склоношћу ка истини (Табела 6). Такође, укупан ниво коруптивности нема систематску пове- 
заност са склоношћу ка правди и дугорочној перспективи. Отуда, можемо констатовати да резултати у потпуности подржавају Х3. О неочекиваној повезаности са склоношћу ка заједничком биће речи касније у тексту.

Табела 6. Корелачије нивоа укупне коруптивности и склоности ка половима у решавағу етичких дилема на раду

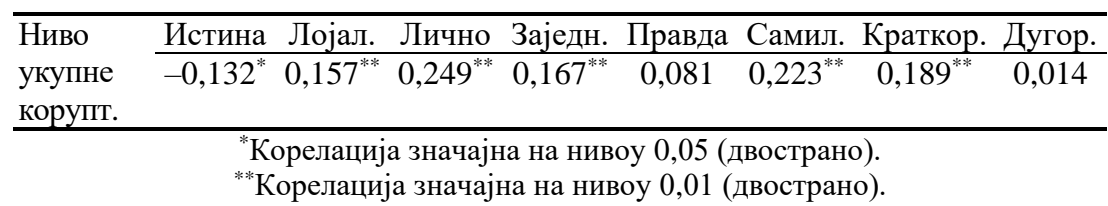

Резултати вишеструких регресијских анализа такође показују да прихватање коруптивних рационализација прогнозира склоности ка личном, краткорочном, самилости, али и склоност ка заједничком (Табела 7).

Табела 7. Регресијски модели полова дилема као критеријским и коруптивним рационализаиијама као предикторским варијаблама

\begin{tabular}{lccccc}
\hline Критеријум & $\mathrm{R}$ & $\mathrm{R}^{2}$ & $\mathrm{df}$ & $\mathrm{F}$ & $\mathrm{p}$ \\
\hline Истина & 0,167 & 0,028 & 6,306 & 1,460 & 0,192 \\
Лојалност & 0,175 & 0,031 & 6,306 & 1,620 & 0,141 \\
Правда & 0,194 & 0,037 & 6,305 & 1,980 & 0,068 \\
Самилост & 0,245 & 0,060 & 6,306 & $3,246^{* *}$ & 0,004 \\
Лично & 0,301 & 0,091 & 6,306 & $5,088^{* *}$ & 0,000 \\
Заједничко & 0,203 & 0,041 & 6,306 & $2,195^{*}$ & 0,043 \\
Краткорочно & 0,256 & 0,065 & 6,306 & $3,565^{* *}$ & 0,002 \\
Дугорочно & 0,165 & 0,027 & 6,306 & 1,429 & 0,203 \\
\hline \multicolumn{5}{c}{${ }^{*}$ Тест значајан на нивоу 0,05 (двострано). } \\
\end{tabular}

Појединачни предиктори оријентације ка „личном” у решавању етичке дилеме „лично насупрот заједничком” рационализације су „порицање одговорности”, $\beta=0,16, \mathrm{t}(306)=2,53, \mathrm{p}<0,01$ и ,порицање жртве", $\beta=0,15, \mathrm{t}(305)=2,20, \mathrm{p}<0,02$. Предиктор склоности ка „краткорочном” је рационализација „порицање жртве”, $\beta=0,19$, $\mathrm{t}(306)=2,76, \mathrm{p}<0,01$, а склоности ка ,самилости” је рационализациja „порицање одговорности”, $\beta=0,13, \mathrm{t}(306)=1,95, \mathrm{p}<0,05$. Предиктори оријентације ка „заједничком” су рационализације „одрицање нелегалности", $\beta=0,12, \mathrm{t}(306)=2,02, \mathrm{p}<0,05$ и „,порицање жртве", $\beta=0,12, \mathrm{t}(305)=1,99, \mathrm{p}<0,05$. Ови налази једним својим делом потврђују очекивање да ће повишен ниво коруптивности бити праћен тенденцијом да се дилеме решавају у корист личног и краткорочног интереса (X3). 
Да ли нам подаци говоре и који конкретни индикатори коруптивних рационализација предвиђају мерене аспекте етичких дилема? У случају два аспекта пола дилеме „лично”, показало се да, када је реч о остварењу личних интереса, значајан допринос остварују ставке о исплативости варања других, $\beta=0,18, \mathrm{t}(305)=3,08, \mathrm{p}<0,02$ и о лагању јер то и други раде, $\beta=0,15, \mathrm{t}(305)=2,58, \mathrm{p}<0,01$. Други аспект „личног” - присвајање туђих заслуга - значајно предвиђају рационализације у смислу прихватљивости крађе, $\beta=0,20, \mathrm{t}(305)=3.69, \mathrm{p}<0,01$ и варања ,јер сви то раде”, $\beta=0,13, \mathrm{t}(305)=2,34, \mathrm{p}<0,02$.

Анализа значаја предиктора склоности према два аспекта краткорочне перспективе у решавању етичких дилема на раду - прихватање брзе зараде и веровање у „боље данас” него у „боље сутра” показује да прихватање брзе зараде прогнозира рационализација „порицање жртве”, по којој треба бити спреман преварити јер ће то и други урадити ако буду имали прилику, $\beta=0,18, \mathrm{t}(309)=3,14$, $\mathrm{p}<$ 0,01 . Склоност краткорочној перспективи у облику веровања у „боље данас" предвиђа ставка о одговорности саме особе да не буде преварена уместо да се одговорност пребацује на особу која је преварила, $\beta=0,12, \mathrm{t}(309)=1,99, \mathrm{p}<0,05$.

Анализа предиктора оријентације ка два аспекта самилости према онима који краду и према онима који крше организацијска правила понашања - показује да, у случају крађе организацијских ресурса због сиромаштва, предиктори су рационализације о томе да сви уоколо краду, $\beta=0,13, \mathrm{t}(309)=2,28, \mathrm{p}<0,02$ и да сви уоколо лажу, $\beta=0,12, \mathrm{t}(309)=2,04, \mathrm{p}<0,05$. Међу коруптивним рационализацијама нема значајних предиктора самилости према онима који крше организацијска правила.

Коначно, детаљнија анализа неочекиване релације нивоа коруптивности и залагања за заједничко у решавању дилеме ,лично наспрам заједничког" заслужује посебну пажњу. Утврђено је да преступ зарад заједничког добра, као један аспект склоности ка „заједничком”, прогнозирају ставке о оправданости преваре ,jер то и други раде", $\beta=0,15, \mathrm{t}(306)=2,61, \mathrm{p}<0,01$, о сопственој одговорности за превару уместо одговорности оног који је преварио, $\beta=0,14$, $\mathrm{t}(306)=2,48, \mathrm{p}<0,01$ и о дозвољености свега оног што законом није забрањено, $\beta=0,13, \mathrm{t}(306)=2,34, \mathrm{p}<0,02$. Међу коруптивним рационализацијама нема значајних предиктора склоности ка заједничком у облику залагања за равноправну поделу награде у тиму.

У Табели 8 лако се може уочити да одређени типови етичке климе у организацији ниско и значајно корелирају са склоношћу ка коруптивним рационализацијама, с тим да неки типови имају негативне или нулте корелације. 
Табела 8. Корелачије типова етичке климе и коруптивних рационализација $(N=313)$

\begin{tabular}{|c|c|c|c|c|c|c|}
\hline & Егоизам & $\begin{array}{l}\text { Профит и } \\
\text { ефикасност }\end{array}$ & $\begin{array}{c}\text { Прија- } \\
\text { тељство } \\
\text { и тим }\end{array}$ & $\begin{array}{c}\text { Социјална } \\
\text { одговорност }\end{array}$ & $\begin{array}{c}\text { Лична } \\
\text { моралност }\end{array}$ & $\begin{array}{l}\text { Правила и } \\
\text { процедуре }\end{array}$ \\
\hline Легалност & $0,175^{* *}$ & 0,096 & $-0,088$ & $-0,037$ & 0,104 & 0,005 \\
\hline $\begin{array}{l}\text { Порицање } \\
\text { одговорности }\end{array}$ & $0,192^{* *}$ & 0,005 & $-0,258^{* * *}$ & $-0,126^{*}$ & $-0,020$ & $-0,053$ \\
\hline $\begin{array}{l}\text { Порицање } \\
\text { штете }\end{array}$ & $0,150^{* *}$ & $-0,071$ & $-0,175^{* *}$ & $-0,131^{*}$ & 0,013 & $-0,122^{*}$ \\
\hline $\begin{array}{l}\text { Порицање } \\
\text { жртве }\end{array}$ & $0,117^{*}$ & 0,008 & $-0,002$ & $-0,016$ & $-0,013$ & $-0,064$ \\
\hline $\begin{array}{l}\text { Социјално } \\
\text { вредновање }\end{array}$ & $0,249^{* *}$ & $-0,026$ & $-0,255^{* *}$ & $-0,132^{*}$ & 0,060 & $-0,141^{*}$ \\
\hline $\begin{array}{l}\text { Лојалност } \\
\text { групи }\end{array}$ & $0,147^{* *}$ & 0,089 & 000 & 0,033 & 0,096 & 0,053 \\
\hline
\end{tabular}

Ако погледамо колону са егоистичном етичком климом, примећујемо да перцепцију такве организацијске етике прати пораст прихватања свих мерених коруптивних рационализација. Насупрот томе, перцепција етичке климе у облику пријатељства и тимског духа, климе социјалне одговорности и климе поштовања правила и процедура код запослених негативно коварира са њиховом склоношћу ка неким коруптивним рационализацијама. Коначно, два типа етичке климе - клима која потенцира профит и радну ефикасност или клима која омогућује развој личне моралности - нису повезани са степеном прихватања било које коруптивне рационализације. Ови налази потврђују очекивање (X4) да егоистична етичка клима представља контекст у којем запослени прихватају или сами развијају различите коруптивне рационализације.

\section{Дискусија резултата}

Основни циљ овог рада био је да се испита значај перцепције организацијске етичке климе, склоност коруптивним рационализацијама и неких демографских одлика за преференцију појединих полова у решавању етичких дилема типичних за организацијски контекст.

Резултати показују да опажање етичке климе у организацији као егоистичне или друштвено одговорне утиче на појаву склоности запослених да се у решавању етичке дилеме „правда наспрам самилости" опредељују за самилост. Конкретно, у таквом етичком амбијенту запослени су спремнији да опросте онима који краду због сиромаштва и онима који крше организацијска правила. Да би био објашњен, неочекивани однос климе егоизма и самилости захтевао је додатне анализе. Претпостављено је да иза самилости према крађи 
имовине организације (дакле коруптивног понашања) стоји одређена коруптивна рационализација која није предиктор самилости према онима који крше организацијска правила. Накнадним анализама то је и потврђено, односно, добијен је значајан регресијски модел, $\mathrm{R}^{2}=$ $0,06, \mathrm{~F}(6,306)=2,95, \mathrm{p}<0,01$, у коме рационализације порицање штете, $\beta=0,17, \mathrm{t}(306)=2,35, \mathrm{p}<0,02$ и порицање одговорности, $\beta=$ $0,13, \mathrm{t}(306)=1,96, \mathrm{p}<0,05$ значајно предвићају самилост према крађи. Као што је и очекивано, регресијски модел са истим предикторима и са самилошћу према онима који прекрше организацијска правила као критеријском варијаблом није био статистички значајан, $\mathrm{R}^{2}=$ $0,04, \mathrm{t}(6,306)=1,96, \mathrm{p}>0,05$. Овај налаз значи да склоност ка самилости може бити детерминисана индивидуалним коруптивним уверењима која служе увек и само за промоцију личног интереса. Отуда и појава значаја егоистичне етичке климе за самилост према контрапродуктивном понашању као што је крађа. У недостатку сличних истраживања, овај налаз може бити само индиректно упоређен са резултатима претходних истраживања, према којима награђивање искључиво финансијског ефекта рада (егоистичка клима) ствара услове за чешће неетично понашање (Ghosh, 2008). Индиректно поређење је једино могуће из разлога што решавање етичких дилема никада не води опредељењу за неетично решење које је у сукобу са свим етичким стандардима, него само за решење које је више или мање неетично (оно је само мање прихватљиво са неког другог етичког становишта). Тек развијени етички програм којим се не промовише егоизам него другачија клима може подстаћи и више етичног понашања. Наиме, у клими социјалне одговорности у којој се запослени активно залажу за благостање клијената компаније, они сами постају склонији да чувају благостање својих колега, и то тако што су спремни да покажу самилост према њему/њој ако прекрши организацијска правила. Отуда, можемо констатовати да етичка клима утиче на начин решавања етичких дилема тако што производи или коруптивна или аутентична индивидуална уверења спрам којих се запослени, унутар „егоистичне” или „климе социјалне одговорности” опредељује за самилост када решава дилему ,самилост наспрам правде”.

Када је реч о значају демографских одлика запослених за начин решавања етичких дилема, у недостатку сличних истраживања, наши резултати могу бити само индиректно валидирани спрам неких од њих. Тако, уколико деонтолошку моралност схватамо као виши ниво моралности, тада ћемо налаз да се жене више залажу за „истину" схватити еквивалентним налазу да жене показују виши ниво моралности (Becker, Rundall \& Ulstad, 2009; Valentine \& Rittenburg 2007; Lawson, 2004). Насупрот томе, наш налаз да мушкарци значајно чешће подржавају „лојалност” у решавању исте етичке дилеме можемо разумети као манифестацију утилитаристичке моралности, у 
складу је са резултатима претходних истраживања (нпр., Zgheib, 2005). Такође, наши налази о незначајном ефекту нивоа образовања на морално суђење у складу са претходним истраживањима (нпр., Marques \& Azevedo-Pereira, 2009). Међутим, значајне разлике између најмлађе и најстарије групе запослених, у смислу да се најмлађи чешће него најстарији запослени оријентишу према „личном”, није у сагласности са претходним налазима, по којима старост нема ефекта на етичко суђење (нпр., Herington \& Weaven, 2008). Транзиција нашег друштва и све јача оријентација према вредностима либералног капитализма вероватно налази своје упориште у млађим генерацијама, које свој успех у таквим околностима виде управо у промоцији личног интереса.

Када је реч о значају склоности ка коруптивним рационализацијама за оријентацију на начин решавања етичких дилема, утврђено је да оваква уверења предвиђају јачу склоности ка решењима етичких дилема која значе јаче залагање за лични и краткорочни интерес, као и слабије залагање за истину. Конкретно, они запослени који су склони да избегавају личну одговорност за последице свог понашања, као и да одричу постојање штете изазване промоцијом сопственог интереса - склонији су и да се залажу за заштиту личног и краткорочног интереса. Ове рационализације се вероватно заснивају на уверењима о исплативости варања, крађе и лагања, као и уверења да то сви други стално раде. Заступање егоистичног интереса вероватно је праћено и перцепцијом тако изазване штете некој другој страни, што код актера доводи до стања етичке дисонанце и потребе за њеним разрешењем. На пример, руководилац може захтевати повећање своје плате у тренутку тешком по организацију уз образложење да на то има право према правилнику о награђивању, зато што он то заслужује и зато што то иначе сви траже чим задовоље прописане критеријуме.

Занимљив је налаз да склоност коруптивним рационализацијама да „сви уоколо краду”, као и да „сви лажу” - корелира са самилошћу према онима који због немаштине краду у организацији. Овде највероватније није реч о самилости према некој конкретној особи, него о понашању других које је слично намерама оног који ту самилост показује. У случају залагања за заједничко, и то у облику чињења преступа зарад користи за организацију, установљено је да је таква склоност заснована на коруптивним уверењима да „сви варају”, „да је боље преварити него бити преварен” и да „све што законом није забрањено то је и дозвољено". Утисак је да ова група рационализација може да представља „филозофски” оквир за системску корупцију у организацији. Наиме, ове рационализације обухватају најшири социјални контекст (културу варања), законски оквир који се тумачи да то дозвољава и, коначно, препоручује „одговарајући” индивидуални образац понашања у таквом амбијенту. Коначно, на- 
лаз да коруптивне рационализације не предвиђају склоности запослених ка правди, дугорочној перспективи, лојалности и истини можемо објаснити тиме да ове етичке вредности припадају деонтолошкој парадигми, која је удаљена од утилитаристичког етичког релативизма.

\section{Практична вредност налаза, ограничења истраживања и будући правичи}

Употребна вредност налаза о значају перцепције етичке климе лежи у њиховој могућој примени на плану унапређења организацијске етике, и то на два начина: 1) као основ за подстицање оне етичке климе која промовише етичке стандарде који су важећи у конкретној организацији и садржани су у начину решавања најчешћих етичких дилема на раду и 2) као основ за увођење механизама контроле и редукције присуства коруптивних рационализација које, ако су раширене и запослени их прихватају, недвосмислено указују на развијеност егоистичне етичке климе, као и на спремност за ризично понашање и корупцију.

Једно од ограничења овог истраживања је свакако коришћење пригодног узорка за прикупљање података. Било би корисно узорковати на начин да се обухвате индустрије, као и организацијски нивои, чиме бисмо могли утврдити стратумску учесталост етичких дилема, као и начина њиховог решавања, било унутар организацијских нивоа или између организација/сектора индустрије. Требало би даље развијати мере склоности ка одређеним половима етичких дилема на раду, што би допринело ваљаности и поузданости супскала упитника Е-Дил. Такође, потребно је даље развијати модел решавања етичких дилема на раду као специфичан облик етичког одлучивања.

\section{ЗАКЉУЧАК}

Истраживање је имало за циљ да се утврди значај етичке климе и степена прихватања коруптивних рационализација у организацији за начин решавања четири етичке дилеме типичне за радни контекст - „истина насупрот лојалности”, „лично насупрот заједничког”, „краткорочно насупрот дугорочног” и „правда насупрот самилости”. Анализа значаја перцепције етичких стандарда и праксе у организацији за прихватање коруптивних рационализација недвосмислено је показала да перцепција егоистичне етичке климе чини контекст у коме се прихватају сви мерени типови коруптивних рационализација. Конзистентно са нашим схватањем да је прихватање коруптивних рационализација показатељ нивоа коруптивности, можемо констатовати да организација у којој се промовише остварење личних циљева и интереса представља повољан амбијент за корупцију радне етике, а самим тим и за настанак рационализација потреб- 
них у решавању стања етичке дисонанце изазване коруптивним понашањем. Насупрот томе, етичка клима пријатељства и тима, клима правила и процедура, као и клима социјалне одговорности доприносе тенденцији одбацивања три од шест мерених коруптивних рационализација. Закључено је да перцепција етичке климе у организацији индиректно утиче на начин решавања етичких дилема на раду, и то тако што код запослених генерише уверења о важности одређених етичких тема (нпр., принципи понашања који воде заштити личног интереса или принципи понашања који воде заштити личног благостања), који потом утичу на запослене да се определе за решења етичких дилема са којим су та уверења у складу.

\section{ЛИТЕРАТУРА}

Anand, V., Ashforth, B. E., \& Joshi, M. (2004). Business as usual: The acceptance and perpetuation of corruption in organizations. Academy of Management Perspectives, 18(2), 39-53.

Andrijanić, A. (2018). Etički izazovi istraživanja nasilja nad djecom u obitelji. [Ethical challenges in research on child abuse in a family]. (Doctoral dissertation, University of Zagreb. Faculty of Law. Methodology of Research in Social Work and Social Policy.).

Aquino, K., \& Reed, I. I. (2002). The self-importance of moral identity. Journal of personality and social psychology, 83(6), 1423.

Aschforth, B. E., \& Anannd, V. (2003). The normalization of coruption in organizations. In R. M. Kramer \& B. M. Staw (Eds.), Research in organizational behavior, 25, 152. Amsterdam: Elsevier.

Barkan, R., Ayal, S., Gino, F., and Ariely, D. (2012). The pot calling the kettle black: distancing response to ethical dissonance. Journal of Experimental Psychology, 141,757-773.

Barkan, R., Ayal, S., \& Ariely, D. (2015). Ethical dissonance, justifications, and moral behavior. Current Opinion in Psychology, 6(DEC), 157-161.

Becker, D., Rundall, J., \& Ulstad, I. (2009). The ethic of care and student cheating. The Journal of American Academy of Business, 14(2), 204-209.

Bjørnskov, C., "The happy few: Cross-country evidence on social capital and life satisfaction," Kyklos, 56(1), 2003, 3-16.

Briggs, S. R., \& Cheek, J. M. (1986). The role of factor analysis in the development and evaluation of personality scales. Journal of personality, 54(1), 106-148.

Brommer, M., \& Gratto, C. Gravender, and Tuttle, M. (1987). A behavioral model of ethical and unethical decision making. Joumal of Business Ethics, 6, 265-280.

Chaiken, S., Giner-Sorolla, R., \& Chen, S. (1996). Beyond accuracy: Defense and impression motives in heuristic and systematic information processing. In P. M. Gollwitzer \& J.A. Bargh (Eds.), The psychology of action: Linking cognition and motivation to behavior (pp. 553-578). New York: Guilford Press.

Cherry, J., \& Fraedrich, J. (2000). An empirical investigation of locus of control and the structure of moral reasoning: Examining the ethical decision-making processes of sales managers. Journal of Personal Selling \& Sales Management, 20(3), 173-188.

Chiu, R. K. (2003). Ethical judgment and whistleblowing intention: Examining the moderating role of locus of control. Journal of business ethics, 43(1-2), 65-74. 
Cullen, J. B., Victor, B., \& Bronson, J. W. (1993). The ethical climate questionnaire: An assessment of its development and validity. Psychological reports, 73(2), 667-674.

Dai, J. (2012). A review of the empirical literature on ethical decision-making: 20042010. Available at SSRN: http://ssrn.com/abstract=2344521

Donev D. \& Kaluđerović Ž. (2016). Etičke dileme u novim medijima.[Ethical dilemmas in new media]. Mediji i komunikacije. 3(5), 115-125.

Dragin, A., Jovanovic, T., Mijatov, M., Autor. \& Dragin, V. (2018). Types and Factors of Ethical Climate Perception in Serbian Tourism Industry. Journal of East European Management Studies, Special Issue, 63-99.

Dubinsky, A. J., \& Loken, B. (1989). Analyzing ethical decision making in marketing. journal of Business Research, 19(2), 83-107.

Elango, B., Paul, K., Kundu, S. K., \& Paudel, S. K. (2010). Organizational ethics, individual ethics, and ethical intentions in international decision-making. Journal of Business Ethics, 97(4), 543-561.

Ferrell, O. C., Fraedrich, J. \& Ferrell, L. (2010). Business ethics: Ethical decision making \& cases. South Western Educational Publishing.

Ferrell, O. C., \& Gresham, L. G. (1985). A contingency framework for understanding ethical decision making in marketing. Journal of marketing, 49(3), 87-96.

Ferrell, O., Gresham, L. G., \& Fraedrich, J. (1989). A synthesis of ethical decision models for marketing. Journal of Macromarketing, 9(2), 55-64.

Festinger, L. (1962). A theory of cognitive dissonance (Vol. 2). Stanford university press.

Fraedrich, J., \& Ferrell, O. C. (1992). Cognitive consistency of marketing managers in ethical situations. Journal of the Academy of Marketing Science, 20(3), 245-252.

Garcia, J. de Jesus, N. C. Fuentes, S.A. Borrego, M.D. Gutierrez, \& Tapia, A. (2007) Values and happiness in Mexico: The case of the metropolitan city of Monterrey," in L. Bruni and P L. Porta (eds.), Handbook on the Economics of Happiness, (pp. 407-428). Cheltenham, UK: Edward Elgar.

Ghosh, D. (2008). Corporate values, workplace decisions and ethical standards of employees. Journal of Managerial Issues, 68-87.

Greenwald, A. G. (1980). The totalitarian ego: Fabrication and revision of personal history. American psychologist, 35(7), 603-618.

Herington, C., \& Weaven, S. (2008). Improving consistency for DIT results using cluster analysis. Journal of Business Ethics, 80(3), 499-514.

Hunt, S. D., \& Vitell, S. (1986). A general theory of marketing ethics. Journal of macromarketing, 6(1), 5-16.

James Jr, H. S. (2011). Is the just man a happy man? An empirical study of the relationship between ethics and subjective well-being. Kyklos, 64(2), 193-212.

Jones, T. M. (1991). Ethical decision making by individuals in organizations: An issue-contingent model. Academy of management review, 16(2), 366-395.

Кесић, 3., \& Зекавица, Р. (2013). Правне и етичке дилеме полицијске професије. [Legal and ethical dilemmas in a police profession]. Супротстављање савременом организованом криминалу и тероризму, 4, 247-262.

Kidder, R. M. (1995). How good people make tough choices. New York: Morrow.

Kohlberg, L. (1984). Essays on moral development: Vol. 2. The psychology of moral development, San Francisco: Harper \& Row.

Kolarski, M. (2019). Značaj etičke klime i nivoa izgaranja u radu za učestalost simptoma poremećaja psiho-fizičkog zdravlja zaposlenih. [The significance of an ethical climate and burnout at work for occurence of ill-health symptoms among employee's]. Master rad. Univerzitet u Novom Sadu, Filozofski fakultet.

Lawson, R. A. (2004). Is classroom cheating related to business students' " propensity to cheat in the" real world"?. Journal of business ethics, 49(2), 189-199. 
Loe, T. W., Ferrell, L., \& Mansfield, P. (2000). A review of empirical studies assessing ethical decision making in business. Journal of business ethics, 25(3), 185-204.

Мајсторовић, Н. (2011). Упитник коруптивних рационализација (Коптер). Необјављен материјал.

Мајсторовић, Н. (2012). Корупција: узроци, експанзија и интервенција [Corruption: causes, expansion and intervention]. Академска књига. ISBN: 978-86-6263-006-3.

Мајсторовић и Слијепчевић (2018). Упитник етичке климе ECQ, превод и адаптација. Необјављен материјал.

Мајсторовић, Пилиповић, Ђајић и Ристић, (2018). Упитник етичких дилема на раду (Е-Дил-3). Необјављен материјал.

McDevitt, R., Giapponi, C., \& Tromley, C. (2007). A model of ethical decision making: The integration of process and content. Journal of Business ethics, 73(2), 219-229.

Marques, P. A., \& Azevedo-Pereira, J. (2009). Ethical ideology and ethical judgments in the Portuguese accounting profession. Journal of Business Ethics, 86(2), 227-242.

Martinović, M. (2012). Značaj self-regulacije ponašanja, lokusa kontrole i makijavelizma za prihvatanje koruptivnih racionalizacija. (Significance of self-regulation of behavior, controlling locus and macawavelism for accepting corrupt rationalization.) Master rad. Univerzitet u Novom Sadu, Filozofski fakultet.

Matanović, J., Мајсторовић, N. i Mitrić-Aćimović, D. (2011). Koruptivno mišljenje racionalizacije, njihovo značenje, tipovi i prisustvo. (Corruptive thinking rationalization, their meaning, types and presence.) Saopštenje na međunarodnom naučno-stručnom skupu Savremeni trendovi u psihologiji, 14 - 16. 10. 2011. Univerzitet u Novom Sadu, Filozofski fakultet, Odsek za psihologiju. Knjiga rezimea strana $287-288$.

Nielsen, M. B., Tangen, T., Idsoe, T., Matthiesen, S. B., \& Magerøy, N. (2015). Posttraumatic stress disorder as a consequence of bullying at work and at school. A literature review and meta-analysis. Aggression and violent behavior, 21, 17-24.

O'Fallon, M. J., \& Butterfield, K. D. (2005). A review of the empirical ethical decisionmaking literature: 1996-2003. Journal of business ethics, 59(4), 375-413.

Peterson, D., Rhoads, A., \& Vaught, B. C. (2001). Ethical beliefs of business professionals: A study of gender, age and external factors. Journal of Business Ethics, 31(3), 225-232.

Paliwal, M. (2006). Business Ethics. New Age International (P) Ltd., New Delhi.

Rabl, T., \& Kühlmann, T. M. (2009). Why or why not? Rationalizing corruption in organizations. Cross Cultural Management: An International Journal, 16(3), 268-286.

Rest, J.R. (1979). Development in Judging Moral Issues. University of Minnesota Press, Minneapolis, MN.

Secchi, D. (2007). Utilitarian, managerial and relational theories of corporate social responsibility. International Journal of Management Reviews, 9(4), 347-373.

Singhapakdi, A., Vitell, S. J., \& Franke, G. R. (1999). Antecedents, consequences, and mediating effects of perceived moral intensity and personal moral philosophies. Journal of the Academy of Marketing Science, 27(1), 19-36.

Sonenshein, S. (2007). The role of construction, intuition, and justification in responding to ethical issues at work: The sense making-intuition model. Academy of Management Review, 32(4), 1022-1040.

Tajfel, H. (1982). Social psychology of intergroup relations. Annual Review of Psychology, 33, 1-39.

Tavits, M., "Representation, corruption, and subjective well-being," Comparative Political Studies, 41(12), 2008, 1607-1630. 
Treviño, L. K. (1986). Ethical decision making in organizations: A person-situation interactionist model. Academy of management Review, 11(3), 601-617.

Treviño, L. K., \& Youngblood, S. A. (1990). Bad apples in bad barrels: A causal analysis of ethical decision-making behavior. Journal of Applied psychology, $75(4), 378$.

Treviño, L. K., Den Nieuwenboer, N. A., \& Kish-Gephart, J. J. (2014). (Un) ethical behavior in organizations. Annual review of psychology, 65, 635-660.

Urbanc, K. (2001). Etika i vrijednosti u socijalnom radu. [Ethics and values in social work]. Ljetopis socijalnog rada, 8(2), 153-164.

Valentine, S. R., \& Rittenburg, T. L. (2007). The ethical decision making of men and women executives in international business situations. Journal of Business Ethics, 71(2), 125-134.

Valentine, S., \& Barnett, T. (2007). Perceived organizational ethics and the ethical decisions of sales and marketing personnel. Journal of Personal Selling \& Sales Management, 27(4), 373-388.

Victor, B. \& Cullen J. B. (1988). The organizational bases of ethical work climate. Administrative Science Quarterly, 33(1), 101-125.

Waters, J. A., \& Bird, F. (1987). The moral dimension of organizational culture. Journal of Business Ethics, 6(1), 15-22.

Witkin, H. A., Moore, C. A., Goodenough, D. R., \& Cox, P. W. (1977). Fielddependent and field-independent cognitive styles and their educational implications. Review of educational research, 47(1), 1-64.

Zgheib, P. W. (2005). Managerial ethics: An empirical study of business students in the American University of Beirut. Journal of business ethics, 61(1), 69-78.

Zyglidopoulos, S. C., Fleming, P. J., \& Rothenberg, S. (2009). Rationalization, overcompensation and the escalation of corruption in organizations. Journal of business ethics, 84(1), 65-73.

\title{
ETHICAL DILEMMAS AT WORK: \\ THE SIGNIFICANCE OF THE ETHICAL CLIMATE AND CORRUPTIVE RATIONALIZATIONS FOR THE RESOLUTION OF ETHICAL DILEMMAS AT WORK
}

\author{
Nebojša Majstorović ${ }^{1 *}$, Tamara Jovanović2 ${ }^{2}$ Bojana Đajić ${ }^{1}$ \\ ${ }^{1}$ University of Novi Sad, Faculty of Philosophy, Novi Sad, Serbia \\ ${ }^{2}$ University of Novi Sad, Faculty of Sciences, Novi Sad, Serbia
}

\section{Summary}

The aim of the research was to determine the importance of organizational ethical climate and the levels of the acceptance of corruption for determining the methods of solving the four ethical dilemmas typical for the working environment - "truth versus loyalty", "individual vs. community", "short-term versus long-term" and "justice vs. mercy" (Kidder, 1995). On an ad hoc sample of 313 employees from different organizations in the Republic of Serbia, an online questionnaire was applied for data collecting on the perception of the organizational ethical climate, the tendency towards corruptive rationalizations as factors in choosing one of the two opposites in solving ethical dilemmas at work. 
The findings indicate the importance of the perception of the egoistic ethical climate and the climate of social responsibility for the willingness of employees to be merciful when solving the dilemma of "justice vs. mercy." It was found that the egoistic ethical climate probably generates the acceptance of corruptive rationalizations that predict the acceptance of "mercy" towards those who steal the company's assets. More specifically, findings demonstrate that rationalizations such as damage denying and responsibility denying predict mercy towards theft. This means that the preference of mercy can also be driven by the promotion of personal interests. On the other hand, the climate of social responsibility influences the employees' preference for mercy for those who break the rules. This is most likely because employees develop beliefs that well-being is important for both the company's clients and colleagues, even when they violate organizational rules. It is considered that the perception of the organizational ethical climate indirectly influences the manner of solving ethical dilemmas at work by generating personal beliefs in employees which, in turn, influence the preference of opposites with which these beliefs are in accordance.

Regarding corruptive rationalizations, it was found that those who incline towards acceptance of rationalizations also prefer more personal, short-term interest and prefer less truth when solving ethical dilemmas. Concretely, employees who avoid personal responsibility for consequences, and those who deny damage caused by the promotion of their interests prefer to protect their personal and short-term interests. As expected, mercy towards others' theft is supported by rationalizations 'everyone steals' and 'everyone lies'. Finally, the perception of egoistic ethical climate is the context where all six corruptive rationalizations are more accepted. In all other types of climate, these rationalizations are rejected or their preferences are unrelated.

Some demographics also play a role in understanding preferences in ethical dilemmas resolutions. Regarding gender differences, this study reveals that males prefer loyalty, short-term and common interests significantly more often, while females prefer the truth. Furthermore, the youngest participants show more preference for personal interests than the oldest ones.

These findings might have practical value in the selection of those employees who prefer ethical dilemmas opposites that are in accordance with ethical standards acceptable in the organization.

The limitations of this research relate to the sample structure because it does not include respondents from different organizational levels or different industries. Besides, the instrument for detecting of ethical dilemmas resolution preferences needs further improvement. 